\title{
Dynamic Intersection of Military and Society
}

\author{
Patricia M. Shields
}

\section{Contents}

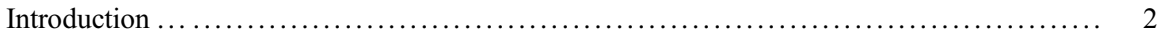

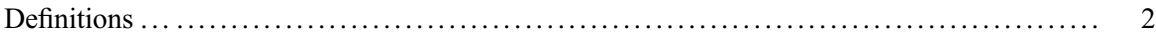

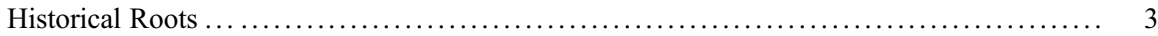

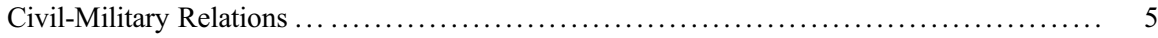

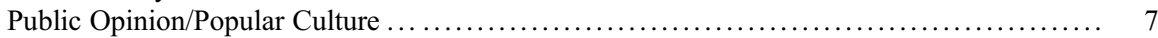

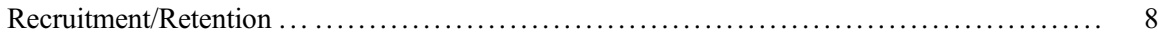

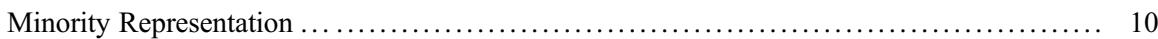

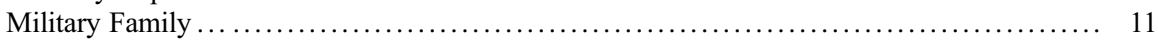

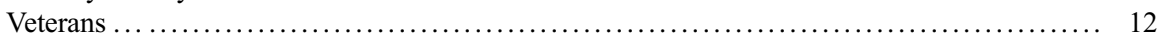

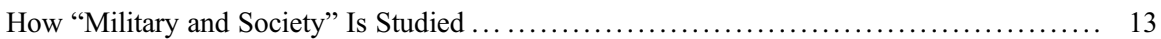

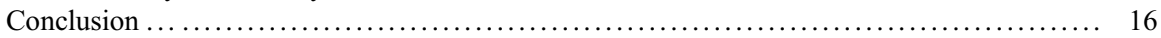

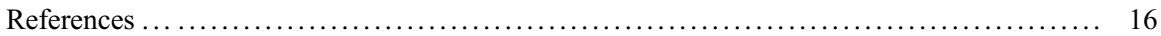

\section{Abstract}

The military and society interact and shape each other every day. This chapter examines the diverse, interdisciplinary field of study that seeks to understand and explain that interaction. It begins by defining and situating the field's origin story in military sociology and political science. Key scholars and events are highlighted to show how the field evolved as the world moved from the Cold War to the War on Terror and beyond. During that time the scope of the field grew incorporating scholars from around the world and across an array of disciplines. The chapter then narrows to discuss key topics central to the field - civil military relations, public opinion/popular culture, recruitment and retention, minority representation (women, minorities, LGBTQ), military families, and veterans'

P. M. Shields $(\triangle)$

Department of Political Science, Texas State University, San Marcos, TX, USA

e-mail:ps07@txstate.edu 
studies. The chapter ends with a discussion and examples of the methods scholars use to study established and emerging research questions.

\section{Keywords}

Civil-military relations $\cdot$ Coups $\cdot$ Civilian control $\cdot$ Enlistment $\cdot$ Military sociology $\cdot$ Military family $\cdot$ Veterans

\section{Introduction}

A nation's armed forces are designed to protect the society it serves. Both military and society have developed norms, rules, and theories which guide and explore this multifaceted relationship. Hobbes, for example, wrote of a "social contract where security is exchanged for the citizen's duty to obey laws of the sovereign power" (Burk 2002, p. 9). Sun Tzu and Clausewitz incorporated insights into this relationship in their classics The Art of War and On War. Sun Tzu speaks of the subservience of the military to the state: "If it is not in the interest of the state, do not act" (Tzu, XII.17), and "In war, the general receives commands from the sovereign" (Tzu, VII.1). Clausewitz's (1984, p. 87) most famous dictum "War is the continuation of politics by other means" speaks directly to politics and the societal objectives embedded in war. Thus, the role of the military as protector in society and the responsibility of the society to the military generate continuing issues and questions that make up the dynamic, multi- and interdisciplinary field of study known as "military and society."

This chapter begins with definitions followed by an examination of the historical and institutional context. Next, topics generally identified as central to the field such as civil-military relations, public opinion, recruitment and retention, minority representation (including women), military families, and veterans are considered. This chapter concludes by examining the diverse methodologies used by scholars in the field.

\section{Definitions}

The "military and society" field of study incorporates the spaces where society and military interact and influence each other. The simple Venn diagram of Fig. 1 illustrates the scope of the field. Dotted lines are used to depict the fluid and dynamic nature of the relationship. External factors such as the security environment, technology, and cultural mores create ebbs and flows which influence both. Also, the size of the overlap can vary. For example, during war the overlay grows dramatically.

The study of military and society examines policy and theoretical issues that arise as "military and civilian sectors negotiate their shared role in society and on the world stage" (Shields 2015, p. 564). It encompasses "all aspects of relations between 
Fig. 1 Military and society

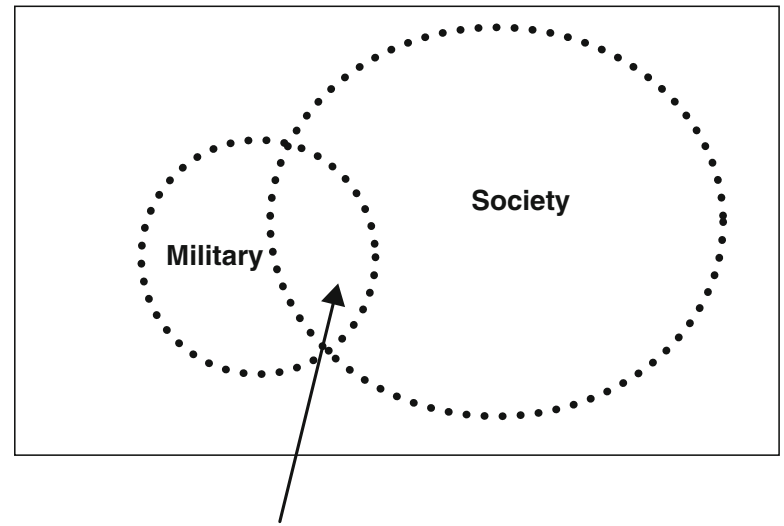

The study of military and society lies at the permeable space where military and society intersect and interact.

armed forces, as a political, social and economic institution, and the society, state or political ethnic movement of which they are a part" (Forster 2005, p. 9).

This umbrella term encapsulates a sometime normative, diverse field which operates across national, organizational, and individual levels of analyses. A few examples illustrate the diversity of the field such as the factors that motivate a sailor to reenlist, the issues a veteran faces finding employment, how communities deal with base closures, civilian and military cooperation in peacekeeping operations, the conditions that lead to coups in failing democracies, disputes between civilian leaders and military advisors about the use of force, how deployed soldiers use social media, how military culture influences the integration of women into combat units, the challenges military families face during post-deployment, public support for the military, and the outsourcing of security.

It should be noted that this field is generally state-centered and that the overlap between military and society and the underlying issues states face can be very different. Compared to Western democracies, for example, African countries have a much higher risk of coups (McGowan 2005). Gay enlisted men and women will have a different experience in countries that have legalized gay marriage and ones that have not.

\section{Historical Roots}

As is clear from the Clausewitz and Sun Tzu quotes, concerns about military and society have a long history. The study of the relationship and connections between the armed forces and society as a self-aware field can be traced to World War II and the Cold War. Although clearly interdisciplinary, two disciplines, political science and sociology, during this period, placed a strong imprint on the study of military and society. Political science, with its robust subfields of international relations and 
security studies, contributed to our understanding of military and society through civil-military relations and the problem of democratic control of the military. In The Soldier and the State, Samuel Huntington (1957) focused on the paradox that a military strong enough to protect the people could also use that power against the polity. Huntington's normative theory addressed the paradox through "objective control" whereby civilians were responsible for political and policy objectives while the armed forces had near-complete discretion in implementation, which meant civilian leaders gave the armed forces autonomy to manage their own affairs. In this environment, it was important to cultivate a strong professional ethos in the officer corps, which reinforced the notion of civilian control.

Sociologist, Samuel Stouffer, another founder of the field, led a team that applied survey research to study the experiences and attitudes of over 500,000 American soldiers in WWII (Stouffer et al. 1949). The American Soldier was a landmark book that ushered in the field of military sociology. Another sociologist, Morris Janowitz (1960), in The Professional Soldier, drew upon civic republican theory to connect soldier and state through the citizen's duty to serve and the society's obligation to those they put in harm's way. This provided a robust, normative, theoretical orientation to view the many interdependencies and interactions between military and society. In Great Britain this relationship has been formalized in the Military Covenant (McCartney 2010).

In the 1970s, after the end of the Vietnam War, the USA transitions from a draft to an All-Volunteer Force. The shift from conscription to volunteer military led to changes in the military organization. This was captured by, sociologist, Charles Moskos's (1977) Institutional-Occupational theory. He postulated that the military was losing its institutional foundations and was becoming more like an occupation where marketplace values displaced traditional values, recruitment appealed to pay increases, use of women increased, and soldiers' work and residence were separated. Although Moskos used the USA as his reference, subsequent studies showed elements of occupationalism in the militaries of Great Britain, France, Australia, Switzerland, the Netherlands, and Germany (Moskos and Wood 1988).

Military sociologist, Morris Janowitz, did more than anyone else to define the "military and society" as a field of study. Aside from contributing through his seminal scholarship and influential students, Janowitz recognized the need for scholars interested in the interface of military and society to develop a forum for exchange of ideas and to organize a professional association. In 1960, he founded the Inter-University Seminar on Armed Forces and Society (IUS) and in 1974 established the journal Armed Forces \& Society, which he edited for 6 years (Sookermany et al. 2017). By 1986, an important sister professional association was formed in Europe - The European Research Group on Military and Society (ERGOMAS). Founders of ERGOMAS such as Giuseppe Caforio (1998) have written key books defining the military and society field of study.

The scholarly focus on topics under the military and society umbrella began during the Cold War when Western democracies operated in a high-threat environment. The dismantling of the Soviet Union ushered in changes captured in The Postmodern Military: Armed Forces after the Cold War by Moskos et al. (2000). 
The changes included greater reliance on volunteer militaries, multipurpose missions, and weaker ties to the nation-state. The brutal terrorist attacks of 11 September 2001 and the subsequent wars in Iraq and Afghanistan further changed the security environment among Western nations testing the ties between military and society and shaping its scholarship in new ways. The challenges of mass migration, cyberattacks, revived nuclear instability, and climate change will surely influence the ways military and society interact into the future. In the next sections, topic areas core to the military and society field are identified and explored, beginning with civilmilitary relations.

\section{Civil-Military Relations}

The field of military and society is intimately tied to civil-military relations, broadly defined as the relationship between civilian and military authorities. The separation of civilian (political) and military (operational) functions put forth by Samuel Huntington in 1957 underlies the literature of civil-military relations. In mature democracies, strong institutions and professional norms ensure civilian authority over national security and use of force decisions. The military generally has authority over doctrine, readiness, tactics, officer education, etc. A public divergence in point of view or preferences of civil authorities (president, prime minister, minister of defense) and military elites can undermine civil-military relations. Although rare, occasionally these differences can rise to open conflict. In the late 1990s, France's Army chief of staff's actions hit the front pages "when he publicly warned the President that the reforms he has initiated would not be implemented if the Prime Minister's recent budget decisions were carried out." Commentators interpreted this as an effort "to drive a wedge between a conservative President and a leftist Cabinet" (Boene 2000, p. 23).

Political scientist, student of Samuel Huntington, and presidential advisor, Peter Feaver (2009) developed a highly regarded theory of civil-military relations relying on principal-agent theory. He depicts civil-military relations as a strategic exchange where civilian principals rely on military agents to implement policy directives. When military and civilian preferences align, the military willingly carries out orders. Alternatively, when preferences deviate, the military has an incentive to shirk or undermine civilian directives. Civilian leaders create monitoring and punishment systems to ensure compliance with orders.

Dale Herspring (2005) developed a theory of civil-military relations, which focused on the personal relationship between elite civilian and military leaders. Civilian leaders rely on the advice of military elite well versed in the geopolitical environment. In day-to-day operations, perceptions of security threats can differ and lead to destructive conflict, which strains the relationship. Herspring found that strong civilian leaders who respect the military culture are best able to weather these conflicts. 
"In the 1990s Dutch and Belgian Chiefs of Staff routinely threatened to resign in protest over drawdowns decisions of which the military disapproved" (Boene 2000, p. 23). Office resignation is a controversial action debated in the pages of Armed Forces \& Society. Don Snider (2017) and James Dubik (2017) believe it is a rare but important tool that should be used by officers. They maintain that resignation gives officers a way to demonstrate moral agency and draw attention to policy that could threaten innocent lives. Richard Kohn (2017) and Peter Feaver (2017) counter that commanders who resign would improperly insert themselves into the policy arena, undermining civilian control.

Risa Brooks (2008) shows how the interplay of civil and military sectors can affect outcomes when states make decisions about fighting wars. She does this by focusing on strategic assessment, the method states use to consider strategies prior to interstate conflict. Flawed strategic assessment such as overstating a nation's military capacity or failing to match military capacities and political goals can result in inept international deliberations and unnecessary war. Brooks (2008) identified information sharing, strategic coordination, authorization, and structural competence as the components of strategic assessment. Whether accepted or not, military leaders should be able to share their point of view candidly. This leads to honest and effective information sharing. Strategic coordination consists of institutional structures that evaluate alternative strategic choices, produce operational plans, and ensure alignment between policy objectives and military actions. Ideally, strategic coordination produces forthright exchanges about assumptions and risks. The immediate problems of translating strategy into action are effectively managed through authorization. Finally, the organizational capacity of the military to be self-reflective, e.g., officer promotion policies tied to competence not politics, refers to structural competence. She found that strategic assessment works best when civil-military agreement is high and civilians control the balance of authority.

Rebecca Schiff's (2012) Concordance Theory focuses on the role of agreement (concordance) "between political and military elites and the citizenry" along four dimensions that "determine the role and function of the armed forces in society: (1) social composition of the officer corps, (2) political decision-making process, (3) recruitment method and (4) military style" (p. 318). She theorizes that when the level of agreement along these dimensions is high, military intervention is less likely. While her theory is applicable for mature democracies, it has been fruitfully applied in emerging democracies where threats of coups are more immediate (Salihu 2019).

Coups, or a military takeover of the government, are extremely rare in mature democracies. Autocracies and other types of unstable states face risks from inside the regime and from threats by popular mobilization (Bove and Rivera 2015). Not surprisingly, the literature of civil-military relations distinguishes between mature democracies, emerging democracies, and weak or unstable states (Degaut 2019; Barak and Miodownik 2019).

Unlike mature democracies, weak or unstable states are much more likely to experience a coup. Violent military coups can be regionally destabilizing and undermine a transition to democracy. The diverse literature on coups examines 
topics such as the factors that lead to coups (McGowan 2005; Bove and Rivera 2015), the value and effectiveness of and steps these governments take to "coupproof" their systems (Albrecht 2015; Rabinowitz and Jargowsky 2018), the recruitment of soldiers by civilians for coups (Kinney 2019), and ways the military can support state transitions to democracy (Degaut 2019).

\section{Public Opinion/Popular Culture}

Underlying democratic control of the military is support by the public for the armed forces and its actions around conflict. Both military and civilian leaders are sensitive to public opinion concerning military policy and the reputation of the armed forces. A gap in perceptions between the public, military, and civilian elite who craft security policy could undermine long-run public support particularly around decisions to use force. The literature examines variables that influence public opinion and asks what does the public know and what is the gap between actual policy and public perceptions? Second, is the public supportive of the military and security policy? And if not, by how much (Steinbrecher and Biehl 2020; Sarigil 2015)? Support for military by the public depends on a host of factors such as socioeconomic status, ideology, education, race, party affiliation, gender, and ethnicity as well as whether a person was native or born abroad (Burbach 2019; Simon et al. 2018).

One of the key questions surrounding public support is concern over civilian and military casualties (Shortland et al. 2019). When will the public support a war with a significant risk of heavy casualties? Using survey data Feaver and Gelpi (2005) examine casualty aversion and find that Americans are not unwilling to accept casualties even in a losing cause.

Public support is particularly important around the use of force. Golby et al. (2018) found that senior military leaders' opinions enhance mission legitimacy (or lack thereof). When military leaders oppose an "interventions abroad, public opposition to the intervention increases" (p. 44). The public tends to follow military opinion in favor of intervention but to a lesser extent.

The literature also asks questions about how the military is portrayed by popular culture, particularly by movies, television shows, videos, and music. By analyzing these media, they gain insight into popular conception of a soldier, veteran, military bureaucracy, combat, etc. For example, Ender (2005) examined the representation of military children in film. He found that the cinema portrayal of the demands of military family life was inconsistent with reality. This study demonstrated a gap between a vision represented by the media and experience. Algra et al. (2007, p. 396) found that the Dutch media portrayal of veterans emphasized "failures and misconduct rather than the sacrifices of veterans." An analysis of how regional news organizations portrayed veterans on their Twitter feed found charity case, hero, and victim as the most common frames (Parrott et al. 2019). In both studies, media used a narrow representation to capture and portray the veteran experience. News media also covers the military during war. Pinder et al. (2009) 
studied how British forces perceived and evaluated the coverage. They found dissatisfaction with coverage, particularly when it led to undue fear among their families. The authors concluded that the media coverage can affect morale through its influence on the family.

Service members use media to communicate and maintain contact with family and friends during absences. Schumm et al. (2004) examined the use of letters, telephone calls, email, and audio or videotapes by deployed peacekeepers. The widespread use of social media platforms like Facebook has given soldiers the opportunity to network with their compadres and share their everyday frustrations and lighthearted moments (Stern and Ben Shalom 2019).

\section{Recruitment/Retention}

The military relies on members of society to fill its ranks. The literature on recruitment and retention generally focuses on efficiency, effectiveness (Woodruff 2017), civic responsibility, equity or fairness (Shields 1980), and motivation to enlist or reenlist (Woodruff et al. 2006). The Army takes civilians and turns them into soldiers. High-tech militaries seek recruits with the mental and physical ability to meet this challenge. New service members should also be able to adapt to the military culture and adopt its values. At the same time, the risks of military service and the importance of having an armed force that more or less resembles the society that it serves are also consideration (Liebert and Golby 2018, Hauser 2018). Universal conscription can enhance bonds and ties to the military and promote a civic culture (Wallenius et al. 2019).

A countries' recruitment method, volunteer or draft, depends, in part, on the threat level. Nations in a high-threat environment generally use conscription to ensure they have enough warriors to protect the nation. Currently, Israel and South Korea both rely on conscription. Cohn and Toronto (2017, p. 436), in a study of 99 countries over 40 years, examined when conscription or volunteer systems were used. They found that "states with British origins were less likely and those experiencing greater external threat were more likely to use conscripts" (p. 436). Further, states with tightly regulated labor markets were more likely to employ a draft. Are there battlefield consequences for the use of conscription? Yes, according to research by J. Paul Vasquez (2005). His study showed that democracies with conscription tend to have fewer casualties. This is attributed to greater political power among people affected by the draft to constrain policy makers.

Political and military leaders face unique fairness and equity issues when compelling military service particularly amid war (Shields 1981). During the Cold War, Western militaries generally relied on conscription to meet their manpower quotas. Under this system, the military could easily meet recruitment targets and automatically exclude individuals who failed to meet minimum requirements. After the Cold War, the militaries of Western Europe no longer needed to maintain a mass army. This eliminated a compelling need for conscription. As a result, most Western 
nations have ended or modified their compulsory systems. Many of these systems retain draft registration and have begun requiring women to register (Bieri 2015).

When militaries transition to a volunteer system, they must compete in the labor market. This results in a very different set of constraints and organizational problems. Enlistment and the factors that motivate regular or reserve enlistment become among the most important concerns of volunteer militaries. Most studies, which examine enlistment motivation, draw in part from the Moskos InstitutionalOccupational model. These studies examine enlistment motivation incorporating two sometimes competing underlying motivations - self-interest (pay) and intrinsic values that align with patriotism, duty, adventure, etc. Empirical studies consistently find that both self-interest and nonmarket values like love of country, adventure, and comradeship explain enlistment behavior (Bury 2017; Eighmey 2006; Griffith 2008). Genetic predisposition, family ties, or having a relative who serves also can increase the likelihood of serving in the military (Johnson and Lidow 2016; Miles and Haider-Markel 2019).

Militaries commit significant resources training and socializing their service members, who sign up for a specific tour of duty. Scholars study retention and reenlistment motivation because effective and cohesive militaries need to retain the skill and knowledge base of a sizable set of its initial recruits (Hoglin and Barton 2015). Unlike the new recruit, existing service members consider their experience with military culture and organization in their decision to reenlist or leave. Studies have shown that intrinsic attachment to the military has "positive effect on perceptions of the organization, social satisfaction, organizational identification and discretionary pro-organizational behaviors" which are associated with reenlistment (Woodruff 2017, p. 579). Self-interest also has a role; Jaiswal et al. (2016) found that extrinsic factors like low pay and job satisfaction as well as poor promotion opportunities were associated with attrition.

Critics of volunteer systems generally focus on the way it disconnects military service from civic duty and undermines the connection between military and a broad spectrum of society (Moskos 1981; Hauser 2018). This could result in an isolated military unrepresentative of the citizenry it serves.

Postmodern militaries also use contractors to take over functions previously performed by service members. This practice and the functions covered by contractors have grown substantially over the course of the last 30 years. As military contractors serve in combat zones and experience the inevitable combat-related death and injury, questions arise about the responsibility of society to private soldiers (Riley and Gambone 2016). Research on use of private security contractors is challenging because private companies can legally shield their business operations from public scrutiny. Swed et al. (2018) creatively took on this challenge by using publicly available records of contractor war dead as a proxy for contractor labor. 


\section{Minority Representation}

Military and society are interdependent. The military is shaped by the culture and belief systems of society and mirrors practices of the larger culture. Sometimes this leads to policies of exclusion or marginalization. Scholars have examined this phenomenon. The historical use of women is perhaps the most studied example (Fasting and Sand 2010). For millennia, the military ranks were purposefully filled by men. Women's formal responsibilities were limited to roles such as spies or prostitutes existing at the fringes of the camps (Holm 1992).

Variables such as military exigency, public opinion, culture, and technology have contributed to the very slow integration of women as full participants into the world's armed forces (Segal 1995; Shields 1988). One important example occurred when the newly developed telegraph brought news of the high death by disease rate among British troops during the Crimean War (1853-1856). Queen Victoria, adopting a mother-of-the-troops role, supported a radical solution. Great Britain sent Florence Nightingale and a cadre of women nurses to provide succor to the suffering troops and to save lives by incorporating newly recognized sanitary practices to the running of the filthy military hospital in Scutari. Although Nightingale faced stiff opposition from the military establishment, she and her nurses turned things around and lowered the rate of death by disease. Letters from recovering soldiers also influenced public opinion and helped to change attitudes. This example illustrates the power of the society/military interface. New trends in society (technology, public opinion, and a maternalistic Queen-as-ruler) changed the way an empire utilized women in its military (Attewell 1998; Shields and Rangarajan 2011). Nightingale's nurses did not wear a uniform; they did, however, pave the way for uniformed military nurses during WWI and WWII (Hacker 1981).

As women achieved the right to vote and pushed for additional responsibilities outside the home, Western military organizations have worked, struggled, and eventually succeeded in integrating women into all aspects of the force. The literature of women's integration is more diverse and polarized than most literature dealing with other "military and society" subjects. Scholars like Cynthia Enloe (2000) look at women in the military through the broader lenses of feminism and militarization of women's lives. Koeszegi et al. (2014) examine the challenges women soldiers in Austria face while working in a masculine culture of workplace aggression. Conservative critics question women's physical ability to serve as combatants and raise concerns about military effectiveness, readiness, and cohesion (Van Creveld 2000; Browne 2007). Empirical studies document the integration of women by analyzing organizational practices and policies and examining the attitudes and experiences of women and men service members as they participate in the transition (Cawkill et al. 2009). These issues are pertinent throughout the world even in places where women's rights are restricted. For example, Nilsson (2018) explored the experiences of Muslim mothers who serve as combat soldiers in Kurdistan, and Maffey and Smith (2020) studied Jordanian women who are stretching the traditional sex role boundaries while serving their society. 
Military scholars have also turned their attention to the vexing problem of sexual harassment. Studies using Department of Defense-funded survey data document sexual harassment and then develop and test models to isolate the factors that explain it (Firestone and Harris 1999; Harris et al. 2018). Rosen and Martin (1998) study how harassment affects cohesion at the unit level. Crowley and Sandhoff (2017) studied men in combat units and found they used sexual harassment against military women as a way to communicate their lack of acceptance. The literature also examines ways to solve the problem. John Bennett (2018) argues that the military ethic can be used to develop systemic norms-based preventive policy.

The LGBTQ community represents another minority group receiving scholarly attention. The literature examines the policies of exclusion (Belkin and Levitt 2001, Belkin et al. 2013; Parco et al. 2015) and the experiences of the LGBTQ service members (Okros and Scott 2015). Current literature focuses on transgender acceptance (Ender et al. 2016) and questions about medical procedures and costs (Elders et al. 2015).

Militaries also deal with questions around integration of ethnic, religious, or racial minority groups. Military policies tend to reflect societal attitudes. Sometimes military policy stimulates change within society. Scholars in the field are particularly interested in this kind of dynamic. For example, in the USA, historically African American service members experienced segregation, discrimination, and abuse that paralleled their situation in society. The exigencies of World War II cracked rigid racial lines and gave African Americans an opportunity to demonstrate courage and valor. During the Korean War, troop shortages led President Truman to fully integrate the Armed Forces (1948). Subsequently, the military became a leader in race relations helping to move the entire country to reject racist segregationist policies (MacGregor 1981). Eventually, the military was recognized as a bridging environment that helped American minorities transition into the middle class (Browning et al. 1973).

Immigration patterns over the last 20 years have introduced new minority groups into Western societies. The militaries of these countries have had to adjust to the changing ethnic composition of their forces. One of the most important questions is whether service in the military provides a pathway to citizenship (Sullivan 2019).

\section{Military Family}

The military family sits at the nexus of society and military. The family can be a source of strength, love, and stress for a service member. Both institutions (military and family) require a high level of commitment and are considered "greedy institutions" (Segal 1986). A greedy institution seeks "exclusive and undivided loyalty" (Coser 1974, p.4) and undermines ties to organizations with competing claims. Women, either as service members or military wives, are particularly caught in the greedy web between military and family. They generally have primary responsibility for managing the household and nurturing children (Segal 1986). Women service members face the challenge of managing and thriving in both worlds. Military wives 
often have additional responsibilities as their husbands respond to the demands of the greedy military institution they serve. Much of the literature on military families considers the work-life balance issues facing service members (Carvalho and Chambel 2018; Bellou and Gkousgkounis 2015).

Deployment separates the service member from their family adding home front work for their spouse. Deployment causes anxiety and worry that can result in behavior problems among children. In addition, upon return the service member, their spouse, and children often have adjustment issues (Van Winkle and Lipari 2015; Skomorovsky and Bullock 2017). Military families face more moves than typical families. This can make it difficult for the military spouse to build their career. Studies have found employment and earning gaps between military spouses and their civilian counterparts (Meadows et al. 2016; Hisnanick and Little 2015).

\section{Veterans}

The study of service members who leave the military and return to the civilian world represents a microcosm of the larger study of military and society. Whereas military recruits are inputs that flow from society into the military, veterans represent outputs from the military that reenter society marked by their military experience. Both veteran and society must adapt and adjust to their return. This transition echoes issues such as how families adjust, public opinion about veterans, their voices in politics, challenges faced by women veterans, society's obligations to veterans, and concerns about veteran physical and mental health.

Surprisingly, there is no single definition for a veteran. The UK uses an inclusive definition: "Everyone who has performed military service for at least one day and drawn a day's pay is termed a veteran" (Dandeker et al. 2006, p. 163). The USA establishes veteran status using completion of a minimum period of military service, whereas Australia uses deployment to a conflict zone (Burdett et al. 2013, pp. 4344). Veteran status can also be part of an individual's identity as it is for Zimbabwean soldiers in exile in South Africa (Maringira et al. 2015). Adam White (2018) recently expanded the scope of veteran studies to individual who served in combat zones as private military contractors.

Research on veterans focuses on issues around a successful transition from military to civilian life. "Veterans must navigate a complex cultural transition when moving between environments," and they can expect positive and negative transition outcomes (Cooper et al. 2018, p. 156). Finding suitable employment is generally top of the list of resettlement issues. The employment transition is facilitated when there is an overlap between military and civilian employment (Schulker 2017). In India, retiring veterans face a unique challenge, finding a spouse for their children and caring for their parents (Maharajan and Krishnaveni 2016). Society often develops programs such as education benefits and veterans' preferences in government hiring (Bailey et al. 2019), which can ease the transition.

For many years, the study of veterans almost exclusively looked at male veterans because there were so few women entering and thus few returning to society as 
veterans. Recent scholarship has looked at the experiences of women and found a veterans' advantage for women in the labor market. Women veterans were "overrepresented in higher paying occupations and underrepresented in the lower paying ones," and this was particularly true for women with a disadvantaged background (Padavic and Prokos 2017, p. 368). However, if a woman veteran left with a servicerelated disability, she was more likely to be unemployed (Prokos and Cabage 2017).

Life in the military can be dangerous and violent. Combat experiences can leave soldiers with post-traumatic stress disorder and other lifelong mental and physical health challenges (Hinojosa et al. 2019) which in turn can bring stress and result in family dysfunction, homelessness, drug and alcohol abuse, and suicide (Wolfe-Clark and Bryan 2017). The societal obligation to address these service-related disabilities has led to significant scholarship on programs and policies to mitigate these problems (Feinstein 2015).

Veterans and veteran programs also exert an influence on society. For example, how do veterans vote and establish party affiliation. Jeremy Teigen (2007) found that veterans were basically bipartisan, during the 2004 US presidential election. Christophe Lesschaeve (2019) found that veterans of Croatia's war of independence were more likely to vote for nationalist parties. But among these veterans, those who experienced physical or mental trauma were less likely to support nationalist parties. Studies also examine how veterans are distributed in the legislative bodies and how their presence influences deliberation and legislative agendas (Robinson et al. 2018; Best and Vonnahme 2019). Veterans can also organize and engage in political protest. China's retired officers have organized (occupying government offices, petitions, marches, law suits) to protest a poorly run pension system with delays and serious errors, corruption, and poor post-service employment opportunities (O'Brien and Diamant 2015). There is also evidence that military service can lead to greater civic involvement such as community service (Griffith 2019).

\section{How "Military and Society" Is Studied}

The methodologies used to study this diverse multi-/interdisciplinary field of study are as varied as the field itself. Its diverse methods derive from the many research problems, purposes, and questions found in the field. The methods range from the theoretical and philosophical to practical concerns such as exploring a new program designed to help veterans. Most research and scholarship is empirical, tied to established norms of inquiry and methodological rigor. It also generally supports implicit normative goals such as military effectiveness and professionalism.

The tension around the role of the military in politics can elicit philosophical commentary. For example, Menchaca-Bagnulo (2019) examined how the civic republican tradition in Western political thought adds to the debates surrounding officer resignation. Coletta and Crosbie (2019) drew on Aristotle and Machiavelli to examine virtue in the context of military political behavior. These commentaries link a vast philosophical and theoretical landscape to central issues of the field. 
In the empirical world of data collection, methodological scholars have established three overarching research purposes - explanatory, descriptive, and exploratory (Adler and Clark 2008; Babbie 2007; Shields and Whetsell 2014). These categories are used to frame questions about how scholars of this field use data in their research.

Explanatory research asks the "why" question (Babbie 2007, pp. 89-90), by explaining "why things are the way they are" and by finding "causes and reasons" (Adler and Clark 2008, p. 14). Explanatory research uses hypotheses to articulate relationships. For example, Lewis et al. (2019) wanted to know what explained public support for transgender military members. They hypothesized that an individual's personal experience with transgender people would influence their support. The literature was used to find reasons and empirical evidence (results of other studies) to justify the hypothesis.

Explanatory studies test hypotheses using quantitative data and multivariate statistical tests. For example, Pospieszna and DeRouen (2017) used bivariate probit analysis and the Global Terrorism Database (https:/www.start.umd.edu/gtd/) to examine the influence of civil war mediation on the likelihood of rebel use of violence. For more information on databases used to study conflict, see Ye and Heo (2014). Explanatory research also uses experimental design. Jeremy Teigen (2013) manipulated television advertising and print materials to see the effect of military experience on voters' impression of a candidate's leadership potential and ability to handle defense and security issues.

Although far less common, explanatory research also uses qualitative data. For example, Risa Brooks (2008) wanted to explain the factors that influence the success of strategic assessment. She developed a set of hypotheses and tested them across eight case studies. She used data such as historical records, government documents, records of interviews, historical scholarship, transcripts, and press reports as evidence to test the hypotheses.

Explanatory research is the type of scholarship most often found in highly ranked journals (Avenier and Thomas 2015). In this world the wider the generalizability of the findings, the better. So, comparative studies, which include data from several militaries, would have greater generalizability and likelihood of appearing in a journal. This contrasts with single-country studies or studies that evaluate programs within a military. One should be mindful, however, that if the audience of the study is the military leadership of that country, the study has value because it fulfills a practical need and should be judged by how well it does this.

Descriptive research answers the "what" question and is not concerned with causes (Babbie 2007). Description provides baseline information. Before the "why" questions of explanation can really be formulated, "what" questions should be addressed. When scientists developed the periodic table of the elements, they were not only able to describe the elements, but they were able to use the descriptive framework to develop theories and explain what happens when elements are combined.

Soon after the USA implemented the All-Volunteer Force, scholars and policy makers were concerned that support for the military would drop. David Segal (1975) 
surveyed the public in order to obtain "baseline data on the integration of the military [into society] by considering the civilian context" (p. 216). Forty years later, after the German military moved to a volunteer force, Francesca Fogarty (2015) surveyed soldiers about their perceptions of support for the military by the public. As is common with descriptive studies, both Segal (1975) and Fogarty (2015) used surveys and presented the data using frequency distributions and other forms of descriptive data presentation (charts, graphs). For a useful discussion of survey research in military settings, see Griffith (2014).

Descriptive studies can also ask "what" questions using documents, speeches, newspaper, literature, articles, Twitter, blog posts, and journal articles using content analysis. Sookermany et al. (2017) did a longitudinal content analysis of the articles in Armed Forces \& Society journal to describe trends in authorship and affiliation. They found that over time the journal had proportionally more female authors and that the authors came from more continents, countries, and institutions. Master'slevel students have also used descriptive techniques to analyze the articles of Armed Forces \& Society. Nathan Sexton (2003) used a framework from military sociology developed by Siebold (2001) to classify 117 articles of Armed Forces \& Society between 1998 and 2003. The goal was to describe how the journal covered military sociology topics during the period. Christopher Brady (2010) described articles devoted to peacekeeping in Armed Forces \& Society. He used a framework developed by the United Nations to classify the content of the articles. All the content analysis studies mentioned above used descriptive statistics to summarize their findings.

The scholars who do explanatory and descriptive research are expected to bring an unbiased objectivity to the task. They also tend to use deductive logic, which means the data is collected after a framework has been decided. When scholars test hypotheses, they are using deductive logic. In contrast, most exploratory research uses inductive logic. The qualitative data is collected without expectations of what the results will be. Data informs by speaking for itself. Researcher objectivity is not assumed; rather they are expected to use their experiences to help make sense of the data and to increase understanding of the subject matter (Willis et al. 2007). In-depth exploratory research adds to theory by generating hypotheses or identifying themes.

Exploratory research, like reconnaissance, is a type of inquiry that is in the preliminary or early stages. It "typically occurs when a researcher examines a new interest or when the subject of study itself is relatively new" (Babbie 2007, p. 88). Inductive exploratory research uses qualitative data like direct observation, interviews, focus groups, case studies, and evidence from documents or social media postings. Skomorovsky and Bullock (2017) used focus groups to get an in-depth picture of how children respond to their parent's deployment. They used a grounded theory approach to code the focus group transcripts and identify four themes in their analysis. Neill-Harris et al. (2016) examined "partnerships between the military and local communities by exploring communication channels of the US military and civilian agencies" that provided services to transitioning military members (p. 585). This case study surveyed service providers near a military base and was then 
followed up with interviews. They used the data to make preliminary observations about the partnerships at the case study location and to theorize about the nature of the "uneasy" partnerships they observed.

Neuteboom and Soeters (2017) explored how the Netherlands military personnel performed during periods when the military assumed the police function in three post-conflict areas. This retrospective comparative case study used intensive in-depth interviews and document analysis to trace the process used by the military organizations to deal with the security gap. Exploration can also use direct observation. Resteigne and Soeters (2009) explored the "nature of managerial work" in an ISAF mission by spending a day observing two commanding officers (p. 307). They used management concepts developed by Mintzberg to compare and contrast what they observed with private sector management.

Exploratory research can also have a smaller more practical scope. As part of his master's capstone paper, Bradley Barrett (2017), a combat veteran, who worked for the Texas Veterans Commission explored and provided a preliminary assessment of a new program - Veteran's Treatment Courts. These court programs, which focus on nonviolent offenders, use a jail diversion model and are designed as a non-adversarial approach "where prosecution, defense and judge share the same goal of ensuring participants do not reoffend" (Barrett 2017, p. 5). He interviewed administrators in three Veteran's Treatment Courts and focused his questions on issues identified in the literature - screening participants, continuity of care, and measures of effectiveness. Information from the combination of literature review and interviews allowed him to develop several useful policy recommendations.

\section{Conclusion}

As can be seen by the long bibliography that follows, the literature of the military and society field of study contains many topics and methodologies. The literature highlighted in this chapter touched on most of the high-profile topics of the field. There are many more subjects not covered in this chapter such as the influence and role of religion, the blending of police and military roles, military policies to mitigate climate change, the business of weapon systems, the connection between terrorism and society, organizational responses to the threat of cyber security, and the role of the military in natural disaster. As the security environment evolves and society and military institutions continue to change, scholars and policy makers will be drawn to investigate and explain the links that tie military and society together.

\section{References}

Adler, E., \& Clark, R. (2008). How it's done: An invitation to social research (3rd ed.). Belmont: Thompson-Wadsworth.

Albrecht, H. (2015). The myth of coup-proofing: Risk and instances of military coups d'état in the Middle East and North Africa, 1950-2013. Armed Forces \& Society, 41(4), 659-687. 
Algra, G., Elands, M., \& Schoeman, J. R. (2007). The media and the public image of Dutch Veterans from World War II to Srebrenica. Armed Forces \& Society, 33(3), 396-413.

Attewell, A. (1998). Florence nightingale (1820-1910). Prospects, 28(1), 151-166.

Avenier, M. J., \& Thomas, C. (2015). Finding one's way around various methodological guidelines for doing rigorous case studies: A comparison of four epistemological frameworks. Systemes d'Information Management, 20(1), 61-98.

Babbie, E. (2007). The practice of social research (11th ed.). Belmont: Thompson Wadsworth.

Bailey, A. K., Drury, M. B., \& Grandy, H. (2019). Student veterans' academic performance before and after the Post-9/11 GI Bill. Armed Forces \& Society, 45(1), 101-121.

Barak, O., \& Miodownik, D. (2019). Military autonomy and balancing in political crises: Lessons from the Middle East. Armed Forces \& Society. https://doi.org/10.1177/0095327X19861738.

Barrett, B. (2017). Veterans treatment court programs in Texas: An exploratory research project. Applied Research Project, Texas State University. https://digital.library.txstate.edu/handle/ $10877 / 6585$

Belkin, A., \& Levitt, M. (2001). Homosexuality and the Israel Defense Forces: Did lifting the gay ban undermine military performance. Armed Forces \& Society, 27(4), 541-565.

Belkin, A., Ender, M. G., Frank, N., Furia, S. R., Lucas, G., Packard, G., Samuels, S., Schultz, T., \& Segal, D. R. (2013). Readiness and DADT repeal: Has the new policy of open service undermined the military? Armed Forces \& Society, 39(4), 587-601.

Bellou, V., \& Gkousgkounis, G. (2015). Spouse- and service-related antecedents of officers' commitment: The case of the Greek army. Armed Forces \& Society, 41(3), 440-459.

Bennett, J. (2018). Combating sexual Aasault with the military ethic: Exploring culture, military institutions, and norms-based preventive policy. Armed Forces \& Society, 44(4), 707-730.

Best, R., \& Vonnahme, G. (2019). Military service and legislative agendas: A study of legislators in four states. Armed Forces \& Society. https://doi.org/10.1177/0095327X19848009.

Bieri, M. (2015). Military conscription in Europe: New relevance Center for Security Studies (CSS). CSS Analyses in Security Policy No. 180. https://doi.org/10.3929/ethz-a-010681919.

Boene, B. (2000). Post-cold war trends in the civil control of armed forces in the west. In G. Kummel \& W. Bredow (Eds.), Civil-military relations in an age of turbulence: Armed forces and the problem of democratic control (pp. 11-32). Strausberg: SOWI.

Bove, V., \& Rivera, M. (2015). Elite co-optation, repression, and coups in autocracies. International Interactions, 41(3), 453-479.

Brady, C. (2010). A content analysis of peacekeeping issues for the journal Armed Forces \& Society. Applied Research Project, Texas State University. https://digital.library.txstate.edu/ handle $/ 10877 / 3490$

Brooks, R. (2008). Shaping strategy: The civil-military politics of strategic sssessment. Princeton: Princeton University Press.

Browne, K. (2007). Co-ed combat: The new evidence that women shouldn't fight the nation's wars. New York City: Penguin.

Browning, H. L., Lopreato, S. C., \& Poston, D. L., Jr. (1973). Income and veteran status: Variations among Mexican Americans, Blacks and Anglos. American Sociological Review, 38, 74-85.

Burbach, D. T. (2019). Partisan dimensions of confidence in the U.S. military, 1973-2016. Armed Forces \& Society, 45(2), 211-233.

Burdett, H., Woodhead, C., Iversen, A. C., Wessely, S., Dandeker, C., \& Fear, N. T. (2013). "Are you a veteran?" understanding of the term "veteran" among UK ex-service personnel: A research note. Armed Forces \& Society, 39(4), 751-759.

Burk, J. (2002). Theories of democratic civil-military relations. Armed Forces \& Society, 29(1), $7-29$.

Bury, P. (2017). Recruitment and retention in British Army reserve logistics units. Armed Forces \& Society, 43(4), 608-631.

Caforio, G. (Ed.). (1998). The sociology of the military. Cheltenham: Eduard Elgar Publishing. 
Carvalho, V. S., \& Chambel, M. J. (2018). Work-family conflict and enrichment mediates the relationship between job characteristics and well-being at work with Portuguese Marine Corps. Armed Forces \& Society, 44(2), 301-321.

Cawkill, P., Rogers, A., Knight, S., \& Spear, L. (2009). Women in ground close combat roles: The experiences of other nations and a review of the academic literature. Porton Down: Defense Science and Technology Labroratory.

Clausewitz, C. V. (1984). On war (trans. and ed.: Howard, M., \& Paret, P.). Princeton: Princeton University Press.

Cohn, L. P., \& Toronto, N. W. (2017). Markets and manpower: The political economy of compulsory military service. Armed Forces \& Society, 43(3), 436-458.

Coletta, D., \& Crosbie, T. (2019). The virtues of military politics. Armed Forces \& Society. https://doi.org/10.1177/0095327X19871605.

Cooper, L., Caddick, N., Godier, L., Cooper, A., \& Fossey, M. (2018). Transition from the military into civilian life: An exploration of cultural competence. Armed Forces \& Society, 44(1), 156-177.

Coser, L. A. (1974). Greedy institutions; patterns of undivided commitment. New York: Free Press.

Crowley, K., \& Sandhoff, M. (2017). Just a girl in the Army: U.S. Iraq war veterans negotiating femininity in a culture of masculinity. Armed Forces \& Society, 43(2), 221-237.

Dandeker, C., Wessely, S., Iversen, A., \& Ross, J. (2006). What's in a name? Defining and caring for "veterans": The United Kingdom in international perspective. Armed Forces \& Society, 32(2), $161-177$.

Degaut, M. (2019). Out of the barracks: The role of the military in democratic revolutions. Armed Forces \& Society, 45(1), 78-100.

Dubik, J. M. (2017). Taking a "pro" position on principled resignation. Armed Forces \& Society, $43(1), 17-28$.

Eighmey, J. (2006). Why do youth enlist?: Identification of underlying themes. Armed Forces \& Society, 32(2), 307-328.

Elders, M. J., Brown, G. R., Coleman, E., Kolditz, T. A., \& Steinman, A. M. (2015). Medical aspects of transgender military service. Armed Forces \& Society, 41(2), 199-220.

Ender, M. G. (2005). Military brats: Film representations of children from military families. Armed Forces \& Society, 32(1), 24-43.

Ender, M. G., Rohall, D. E., \& Matthews, M. D. (2016). Cadet and civilian undergraduate attitudes toward transgender people: A research note. Armed Forces \& Society, 42(2), 427-435.

Enloe, C. (2000). Maneuvers: The international politics of militarizing women's lives. Berkeley: Univ of California Press.

Fasting, K., \& Sand, T.S. (2010). Gender and military issues: a categorized research bibliography. Moving Soldiers - Soldaten I bevegelse, 01/2010. https://fhs.brage.unit.no/fhs-xmlui/handle/ $11250 / 99263$

Feaver, P. (2009). Armed servants: Agency, oversight, and civil-military relations. Cambridge: Harvard University Press.

Feaver, P. D. (2017). Resign in protest? A cure worse than Most diseases. Armed Forces \& Society, 43(1), 29-40.

Feaver, P. D., \& Gelpi, C. (2005). Choosing your battles: American civil-military relations and the use of force. Princeton: Princeton University Press.

Feinstein, Y. (2015). The thin line between "crazy" and "Hero": Exploring the multiple statuses of US veterans in a work-therapy program. Armed Forces \& Society, 41(1), 3-22.

Firestone, J., \& Harris, R. (1999). Changes in patterns of sexual harassment in the U. S. military: A comparison of the 1988 and 1995 DoD Surveys. Armed Forces \& Society, 25(4), 613-632.

Fogarty, F. (2015). Backing the Bundeswehr: A research note regarding the state of German civilmilitary affairs. Armed Forces \& Society, 41(4), 742-755.

Forster, A. (2005). Armed forces and society in Europe. Cham, Switzerland: Springer.

Golby, J., Feaver, P., \& Dropp, K. (2018). Elite military cues and public opinion about the use of military force. Armed Forces \& Society, 44(1), 44-71. 
Griffith, J. (2008). Institutional motives for serving in the U.S. Army National Guard: Implications for recruitment, retention, and readiness. Armed Forces \& Society, 34(2), 230-258.

Griffith, J. (2014). Survey research in military settings. In J. Soeters, P. Shields, \& S. Rietjens (Eds.), Routledge handbook of research methods in military studies (pp. 179-193). London: Routledge.

Griffith, J. (2019). Research note: Community service and voting among veterans and nonveterans using a national sample of college undergraduates. Armed Forces \& Society., 46, 323. https:// doi.org/10.1177/0095327X18821399.

Hacker, B. C. (1981). Women and military institutions in early modern Europe: A reconnaissance. Signs: Journal of Women in Culture and Society, 6(4), 643-671.

Harris, R. J., McDonald, D. P., \& Sparks, C. S. (2018). Sexual harassment in the military: Individual experiences, demographics, and organizational contexts. Armed Forces \& Society, 44(1), 25-43.

Hauser, W. L. (2018). Why America should restore the draft: A response to Liebert and Golby's "Midlife crisis? The all-volunteer force at 40." Armed Forces \& Society, 44(1), 181-185.

Herspring, D. R. (2005). The Pentagon and the presidency: Civil-military relations from FDR to George W. Bush (Vol. 14, p. 490). Lawrence: University Press of Kansas.

Hinojosa, R., Hinojosa, M. S., \& Nguyen, J. (2019). Military service and physical capital: Framing musculoskeletal disorders among American military veterans using Pierre Bourdieu's theory of cultural capital. Armed Forces \& Society, 45(2), 268-290.

Hisnanick, J. J., \& Little, R. D. (2015). Honey I love you, but ... investigating the causes of the earnings penalty of being a tied-migrant military spouse. Armed Forces \& Society, 41(3), 413-439.

Hoglin, P. J., \& Barton, N. (2015). First-term attrition of military personnel in the Australian Defence force. Armed Forces \& Society, 41(1), 43-68.

Holm, J. (1992). Women in the military: An unfinished revolution. Aldershot, UK: Gower Publishing Company Ltd.

Huntington, S. P. (1957). The soldier and the state: The theory and politics of civil-military relations. New York: Vintage.

Jaiswal, R. K., Dash, S., \& Mishra, A. (2016). Why do Indian military officers want to leave? An empirical investigation. Armed Forces \& Society, 42(2), 386-406.

Janowitz, M. (1960). The professional soldier: A social and political portrait. Glencoe: The Free Press.

Johnson, T., \& Lidow, N. (2016). Band of brothers (and fathers and sisters and mothers...): Estimating rates of military participation among Liberians living with relatives in the military; A research note. Armed Forces \& Society, 42(2), 436-448.

Kinney, D. H. (2019). Politicians at arms: Civilian recruitment of soldiers for Middle East Coups. Armed Forces \& Society, 45(4), 681-701.

Koeszegi, S. T., Zedlacher, E., \& Hudribusch, R. (2014). The war against the female soldier? The effects of masculine culture on workplace aggression. Armed Forces \& Society, 40(2), 226-251.

Kohn, R. H. (2017). On resignation. Armed Forces \& Society, 43(1), 41-52.

Lesschaeve, C. (2019). Voting after violence: How combat experiences and postwar trauma affect veteran and voter party choices in Croatia's 2003 postwar elections. Armed Forces \& Society., 46, 259. https://doi.org/10.1177/0095327X18819244.

Lewis, D. C., Tadlock, B. L., Flores, A. R., Haider-Markel, D. P., Miller, P. R., \& Taylor, J. K. (2019). Public attitudes on transgender military service: The role of gender. Armed Forces \& Society. https://doi.org/10.1177/0095327X19861737.

Liebert, H., \& Golby, J. (2018). National service and the all-volunteer force: A response to Hauser's "Why America should restore the draft". Armed Forces \& Society, 44(1), 186-192.

MacGregor, M. (1981). Integration of the armed forces 1940-1965. Washington, DC: Center for Military History, United States Army.

Maffey, K. R., \& Smith, D. G. (2020). Women's participation in the Jordanian military and police: An exploration of perceptions and aspirations. Armed Forces \& Society, 46(1), 46-67. 
Maharajan, K., \& Krishnaveni, R. (2016). "Managing the migration from military to civil society": Motivation model for socioeconomic needs in resettlement of veterans in India. Armed Forces \& Society, 42(3), 605-625.

Maringira, G., Gibson, D., \& Richters, A. (2015). "It's in my blood": The military habitus of former Zimbabwean soldiers in exile in South Africa. Armed Forces \& Society, 41(1), $23-42$.

McCartney, H. (2010). The military covenant and the civil-military contract in Britain. International Affairs, 86(2), 411-428.

McGowan, P. (2005). Coups and conflict in West Africa, 1995-2004: Part I theoretical perspectives. Armed Forces \& Society, 32(1), 5-23.

Meadows, S. O., Griffin, B. A., Karney, B. R., \& Pollak, J. (2016). Employment gaps between military spouses and matched civilians. Armed Forces \& Society, 42(3), 542-561.

Menchaca-Bagnulo, A. (2019). Officer resignation and the space between theory and practice. Armed Forces \& Society, 45(3), 532-545.

Miles, M. R., \& Haider-Markel, D. P. (2019). Personality and genetic associations with military service. Armed Forces \& Society, 45(4), 637-658.

Moskos, C. (1977). From institution to occupation: Trends in military organization. Armed Forces \& Society, 4, 41-50.

Moskos, C. (1981). Making the all-volunteer force work: A national service approach. Foreign Affairs, 60, 17.

Moskos, C. C., Williams, J. A., \& Segal, D. R. (Eds.). (2000). The postmodern military: Armed forces after the cold war. Oxford: Oxford University Press.

Neill-Harris, K. A., Resnick, S., Wilson-John, W. M., Miller-Stevens, K., Vandecar-Burdin, T., \& Morris, J. C. (2016). Assessing partnerships between the military and civilian agencies to meet transitioning service members' needs. Armed Forces \& Society, 42(3), 585-604.

Neuteboom, P., \& Soeters, J. (2017). The military role in filling the security gap after armed conflict: Three cases. Armed Forces \& Society, 43(4), 711-733.

Nilsson, M. (2018). Muslim mothers in ground combat against the Islamic State: Women's identities and social change in Iraqi Kurdistan. Armed Forces \& Society, 44(2), 261-279.

O'Brien, K. J., \& Diamant, N. J. (2015). Contentious veterans: China's retired officers speak out. Armed Forces \& Society, 41(3), 563-581.

Okros, A., \& Scott, D. (2015). Gender identity in the Canadian forces: A review of possible impacts on operational effectiveness. Armed Forces \& Society, 41(2), 243-256.

Padavic, I., \& Prokos, A. (2017). Aiming high: Explaining the earnings advantage for female veterans. Armed Forces \& Society, 43(2), 368-386.

Parco, J. E., Levy, D. A., \& Spears, S. R. (2015). Transgender military personnel in the post-DADT repeal era: A phenomenological study. Armed Forces \& Society, 41(2), 221-242.

Parrott, S., Albright, D. L., Dyche, C., \& Steele, H. G. (2019). Hero, charity case, and victim: How U.S. news media frame military veterans on Twitter. Armed Forces \& Society, 45(4), 702-722.

Pinder, R. J., Murphy, D., Hatch, S. L., Iversen, A., Dandeker, C., \& Wessely, S. (2009). A mixed methods analysis of the perceptions of the media by members of the British forces during the Iraq war. Armed Forces \& Society, 36(1), 131-152.

Pospieszna, P., \& DeRouen. (2017). Civil war mediation and rebel use of violence against civilians. Armed Forces \& Society, 43(3), 500-522.

Prokos, A., \& Cabage, L. N. (2017). Women military veterans, disability, and employment. Armed Forces \& Society, 43(2), 346-367.

Rabinowitz, B., \& Jargowsky, P. (2018). Rethinking coup risk: Rural coalitions and coup-proofing in sub-Saharan Africa. Armed Forces \& Society, 44(2), 322-346.

Resteigne, D., \& Soeters, J. (2009). Managing militarily. Armed Forces \& Society, 35(2), 307-332.

Riley, J., \& Gambone, M. D. (2016). Old wounds, new warriors: The problem of contractor medical care during and after contemporary American contingency operations. Armed Forces \& Society, 42(2), 344-361.

Robinson, G. L., Amoroso, J., Wilson, I. (Ike), \& Yon, R. M. (2018). Veterans and bipartisanship. Armed Forces \& Society, 46, 132. https://doi.org/10.1177/0095327X18806515. 
Rosen, L., \& Martin, L. (1998). Sexual harassment, cohesion, and combat readiness in U. S. Army Support Units. Armed Forces \& Society, 24(2), 221-244.

Salihu, N. (2019). Concordance civil-military relations in Ghana's fourth republic. Armed Forces \& Society. https://doi.org/10.1177/0095327X19841665.

Sarigil, Z. (2015). Public opinion and attitude toward the military and democratic consolidation in Turkey. Armed Forces \& Society, 41(2), 282-306.

Schiff, R. L. (2012). Concordance theory, targeted partnership, and counterinsurgency strategy. Armed Forces \& Society, 38(2), 318-339.

Schulker, D. (2017). The recent occupation and industry employment patterns of American veterans. Armed Forces \& Society, 43(4), 695-710.

Schumm, W. R., Bell, D. B., Ender, M. G., \& Rice, R. E. (2004). Expectations, use, and evaluation of communication media among deployed peacekeepers. Armed Forces \& Society, 30(4), 649-662.

Segal, D. (1975). Civil-military relations in the mass public. Armed Forces \& Society, 1(2), 215-229.

Segal, M. W. (1986). The military and the family as greedy institutions. Armed Forces \& Society, 13(1), 9-38.

Segal, M. W. (1995). Women's military roles cross-nationally: Past, present, and future. Gender \& Society, 9(6), 757-775.

Sexton, N. (2003). A description of the articles of the past five years of Armed Forces \& Society. Applied Research Project. Texas State University. https://digital.library.txstate.edu/bitstream/ handle/10877/3744/fulltext.pdf

Shields, P. M. (1980). Enlistment during the Vietnam era and the "representation" issue of the all-volunteer force. Armed Forces \& Society, 7(1), 133-151.

Shields, P. M. (1981). The burden of the draft: The Vietnam years. Journal of Political and Military Sociology, 9(2), 215.

Shields, P. (1988). Sex roles in the military. In C. Moskos \& F. Woods (Eds.), The military: More than a job? Washington, DC: Pergamon-Brassey's.

Shields, P. (2015). Civil military relations. In Encyclopedia of public administration and public policy (3rd ed., pp. 564-569). New York City: Taylor and Francis.

Shields, P., \& Rangarajan, N. (2011). Public service professionals: The legacy of florence nightingale, Mary Livermore and Jane Addams. In D. Menzel \& H. White (Eds.), The state of public administration: Issues, challenges and opportunities (pp. 36-53). Armonl: M. E. Sharpe.

Shields, P., \& Whetsell, T. (2014). Doing practical research and publishing in military studies. In J. Soeters, P. Shields, \& S. Rietjens (Eds.), Routledge handbook of research methods in military studies (pp. 312-325). London: Routledge.

Shortland, N., Sari, H., \& Nader, E. (2019). Recounting the dead: An analysis of ISAF caused civilian casualties in Afghanistan. Armed Forces \& Society, 45(1), 122-139.

Siebold, G. (2001). Core issues and theory in military sociology. Journal of Political and Military Sociology, 29(1), 140-159.

Simon, C. A., Lovrich, N. P., Liu, B., \& Wei, Y. D. (2018). Citizen support for military expenditure post-9/11: Exploring the role of race, ethnicity, and place of birth. Armed Forces \& Society, 44(4), 688-706.

Skomorovsky, A., \& Bullock, A. (2017). The impact of deployment on children from Canadian military families. Armed Forces \& Society, 43(4), 654-673.

Snider, D. M. (2017). Dissent, resignation, and the moral agency of senior military professionals. Armed Forces \& Society, 43(1), 5-16.

Sookermany, A. M., Sand, T. S., \& Ender, M. G. (2017). Authorship and affiliation in armed forces \& society: Developmental trends across volumes 1-41. Armed Forces \& Society, 43(3), 415-435.

Steinbrecher, M., \& Biehl, H. (2020). Military know-nothings or (at least) military knowsomethings?: Knowledge of defense policy in Germany and its determinants. Armed Forces \& Society, 46(2), 302-322. 
Stern, N., \& Ben Shalom, U. (2019). Confessions and Tweets: Social media and everyday experience in the Israel Defense Forces. Armed Forces \& Society. https://doi.org/10.1177/ $0095327 X 19859304$.

Stouffer, S. A., Suchman, E. A., DeVinney, L. C., Star, S. A., \& Williams Jr, R. M. (1949). The American soldier: Adjustment during army life (Studies in social psychology in World War II, Vol. 1). Princeton, NJ: Princeton University Press.

Sullivan, M. J. (2019). Earned citizenship. New York: Oxford University Press.

Swed, O., Kwon, J., Feldscher, B., \& Crosbie, T. (2018). The corporate war dead: New perspectives on the demographics of American and British Contractors. Armed Forces \& Society, 46, 3. https://doi.org/10.1177/0095327X18811375.

Teigen, J. M. (2007). Veterans' party identification, candidate affect, and vote choice in the 2004 U.S. presidential election. Armed Forces \& Society, 33(3), 414- 437.

Teigen, J. M. (2013). Military experience in elections and perceptions of issue competence: An experimental study with television ads. Armed Forces \& Society, 39(3), 415-433.

Tzu, S. (1994). The art of war (Vol. 68). History \& Warfare (Paperback).

Van Creveld, M. (2000). The great illusion: Women in the military. Millennium, 29(2), 429-442.

Van Winkle, E. P., \& Lipari, R. N. (2015). The impact of multiple deployments and social support on stress levels of women married to active duty servicemen. Armed Forces \& Society, 41(3), 395-412.

Vasquez, J. P. (2005). Shouldering the soldiering: Democracy, conscription, and military casualties. Journal of Conflict Resolution, 49(6), 849-873.

Wallenius, C., Brandow, C., Berglund, A. K., \& Jonsson, E. (2019). Anchoring Sweden's post-conscript military: Insights from elites in the political and military realm. Armed Forces \& Society, 45(3), 452-471.

White, A. (2018). Beyond Iraq: The socioeconomic trajectories of private military veterans. Armed Forces \& Society, 44(3), 387-407.

Willis, J., Jost, M., \& Nilakanata, R. (2007). Foundations of qualitative research: Interpretative and critical approaches. Thousand Oaks: SAGE.

Wolfe-Clark, A. L., \& Bryan, C. J. (2017). Integrating two theoretical models to understand and prevent military and veteran suicide. Armed Forces \& Society, 43(3), 478-499.

Woodruff, T. D. (2017). Who should the military recruit? The effects of institutional, occupational, and self-enhancement enlistment motives on soldier identification and behavior. Armed Forces \& Society, 43(4), 579-607.

Woodruff, T., Kelty, R., \& Segal, D. (2006). Propensity to serve and motivation to enlist among American combat soldiers. Armed Forces \& Society, 32(3), 353-366.

Ye, M., \& Heo, U. (2014). The empirical analysis of conflicts, using databases. In J. Soeters, P. Shields, \& S. Rietjens (Eds.), Routledge handbook of research methods in military studies (pp. 238-248). London: Routledge.

\section{Further Reading}

Caforio, G., \& Nuciari, M. (Eds.). (2006). Handbook of the sociology of the military. New York: Springer.

Carreiras, H. (2006). Gender and the military: Women in the armed forces of western democracies. London: Routledge.

Feaver, P., \& Kohn, R. (Eds.). (2001). Soldiers and civilians: The civil-military gap and American National Security. Cambridge: MIT Press.

Finer, S. (2017). The man on horseback: The role of the military in politics. Abingdon: Routledge. Inbody, D. S. (2016). The soldier vote: War, politics, and the ballot in America. Cham, Switzerland: Springer.

Moskos, C. C., \& Wood F. R. (Eds.). (1988). The military: More than just a job? Washington DC: Potomac Books Incorporated. 
Ouellet, E. (Ed.). (2005). New directions in military sociology. North York, Canada: De Sitter Publications.

Pion-Berlin, D. (Ed.). (2003). Civil-military relations in Latin America: New analytical perspectives. Chapel Hill, NC: University of North Carolina Press.

Soeters, J. (2018). Sociology and military studies: Classical and current foundations. London: Routledge.

Teigen, J. (2018). Why veterans run: Military Service in American Presidential Elections 1789-2016. Philadelphia: Temple University press.

Open Access This chapter is licensed under the terms of the Creative Commons Attribution 4.0 International License (http://creativecommons.org/licenses/by/4.0/), which permits use, sharing, adaptation, distribution and reproduction in any medium or format, as long as you give appropriate credit to the original author(s) and the source, provide a link to the Creative Commons license and indicate if changes were made.

The images or other third party material in this chapter are included in the chapter's Creative Commons license, unless indicated otherwise in a credit line to the material. If material is not included in the chapter's Creative Commons license and your intended use is not permitted by statutory regulation or exceeds the permitted use, you will need to obtain permission directly from the copyright holder.

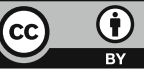

